ORIGINAL ARTICLE

\title{
Effect of salicylidene salicylhydrazide on testes of albino mice: A histomorphological study.
}

\author{
Shagufta Sultana1, Muhammad Haris², Falak Naz ${ }^{3}$, Zainab Rehman ${ }^{4}$, Shazia Iftikhar ${ }^{5}$
}

Article Citation: Sultana S, Haris M, Naz F, Rehman Z, Iftikhar S. Effect of Salicylidene Salicylhydrazide on Testes of Albino Mice: A Histomorphological Study. Professional Med J 2022; 29(1):101-109. https://doi.org/10.29309/TPMJ/2022.29.01.6396

\begin{abstract}
Objectives: To evaluate salicylidene salicylhydrazide (SCS) for any possible toxicological effects on male reproductive system in Albino male BALB/c mice. Study Design: Experimental study. Study Setting: Department of Histopathology, Khyber Medical College Peshawar and Department of Pharmacy, University of Peshawar, Peshawar were utilized for conducting this study. Period: July, 2020 to December, 2020. Material \& Methods: Male BALB/c mice were daily administered with SCS at 5, 25, and $50 \mathrm{mg} / \mathrm{kg}$ for 7 and 14 days. The body and testes weights were measured and the testes were subjected to histological tissue processing techniques. Results: The extent of testicular toxicity was evaluated by using modified Johnsen scoring system for assessing the level of spermatogenesis, and morphometric analysis by measuring the diameter of the seminiferous tubules, thickness of germinal epithelium, and area of interstitial cells of Leydig. The body and testes weights showed that the various doses of SCS have no substantial effects after 7 and 14 days. The tested doses of SCS did not produce any distinguishable change in the normal histological features of seminiferous tubules and interstitium after 7 days. However, after 14 days, the $50 \mathrm{mg} / \mathrm{kg}$ dose of SCS was associated with vacuolization and loosening of germinal epithelium. These mild-to-moderate histopathological aberrations was confirmed from morphometric analysis in this dose group in which a decrease in the seminiferous tubules' diameter and reduction in the thickness of germinal epithelium along with an increase in the interstitial area were observed. Conclusion: These findings concluded that SCS is considered to be relatively safe.
\end{abstract}

Key words: Germinal Epithelium, Reproductive Toxicity Evaluation, Spermatogenesis, Testicular Toxicity Evaluation.

\section{INTRODUCTION}

The preclinical testicular toxicity evaluation of potential drug-like compounds is important and is a standard component of safety assessment during drug development process. ${ }^{1}$ Drugs as well as environmental pollutants have shown to greatly affect the spermatogenesis process during different stages of development in humans. These include cadmium, which severely affect the normal testicular function parameters including decrease testes weight, reproductive hormones, production of oxidative stress and induction of apoptosis in testes. ${ }^{2}$ Conducting toxicological studies on male reproductive system have received greater attention in recent years due to the increasing reports of reduction in the sperm counts along with other reproductive disorders including testicular cancer and possible transmission of exposure-related to the fetus. ${ }^{3}$

Various scientific techniques can be used to evaluate the male reproductive toxicology and these includes general systemic toxicity testing, assessing the functional effects onthe reproductive organs of male, as well as mechanistic and molecular approaches conducted at the tissue level or in isolated cells. ${ }^{4}$ However, assessing the toxicological effect on the male reproductive system in humans is challenging as only a few clinical toxicological markers are available that can monitor possible alterations in testicular function including analysis of semen, testosterone and gonadotropin concentrations in the serum. Moreover, the real time monitoring of adverse
1. MBBS, M.Phil (Anatomy), Lecturer / Demonstrator Anatomy, Khyber Medical College, Peshawar, Pakistan

2. MBBS, M.Phil (Anatomy), Assistant Professor Anatomy, Nowshera Medical College, Nowshera, Pakistan.

3. MBBS, M.Phil (Anatomy), Assistant Professor Anatomy, Khyber Medical College, Peshawar, Pakistan.

4. MBBS, M.Phil (Anatomy), Assistant Professor Anatomy, Khyber Medical College, Peshawar, Pakistan.

5. MBBS, M.Phil (Anatomy), Assistant Professor Anatomy, Khyber Medical College, Peshawar, Pakistan.

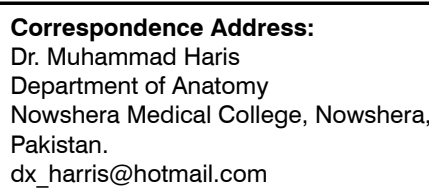


effects on testicular function in humans is also difficult due to the several months of latency period between the time of injury to the seminiferous tubules and the time of its clinical presentation and detection by semen analysis. There is also a dilemma of correlating the measurements of testicular function to changes and effects on male fertility. ${ }^{1}$

Salicylidene salicylhydrazide is the derivative of salicylaldehyde benzoylhydrazone and synthesized by converting alkyl ester to hydrazide by refluxing with excess hydrazine hydrate and addition of aromatic aldehyde. ${ }^{5}$ It has a molecular weight of $256.26 \mathrm{~g} / \mathrm{mol}$ and a melting point of $284-287^{\circ} \mathrm{C}$. It is observed that salicylidene salicylhydrazide has a strong cancer cell damaging potential as it strongly inhibited the growth of human colon adenocarcinoma cells. Its inhibitory anticancer potential $\left(\mathrm{IC}_{50}\right)$ is reported as 1.8, which is more potent than cisplatin (4.2) against these cancer cell lines. ${ }^{5}$ It also strongly inhibits synthesis of DNA in the rodent leukemia and hepatoma cancer cells, human bladder cancer, lung carcinoma and melanoma cells. ${ }^{6}$ Moreover, it also has $\beta 1$ subunit containing $\mathrm{GABA}_{\mathrm{A}}$ receptors inhibitory affinity and the interaction may involve an allosteric mechanism. ${ }^{7}$ Salicylidene salicylhydrazide has an analgesic potential that can be useful for treating peripheral neuropathic pain conditions linked with chemotherapy. ${ }^{8}$

The present study evaluated salicylidene salicylhydrazide (SCS) for any possibility of producing toxicological effects on the male reproductive system, which may compromise its otherwise beneficial effectiveness in diseasestate conditions.

\section{MATERIAL \& METHODS}

The experiments were approved by the Ethical Committee of Khyber Medical College, Peshawar, Pakistan and approval for the study was granted vide registration number $42 / \mathrm{PG} / \mathrm{KMC}$. This was conducted at histopathology department, Khyber Medical College, from July 2020 to December 2020.

Male BALB/c mice weighing 20-40 g were included in the study. They were acclimatized in a light dark cycle of $12 / 12 \mathrm{~h}$ at $20-24^{\circ} \mathrm{C}$. Salicylidene salicylhydrazide (97\%) was obtained from Alfa Aesar, Thermo Fisher Scientific, Kandel, Germany. It was dissolved in a vehicle consisting of DMSO, Tween80 and normal saline in a ratio of $3: 1: 96$.

The mice were divided into four main groups ( $A$, $B, C$ and $D$ ), while groups $B, C$ and $D$ were the experimental groups. Each group was further subdivided into two subgroups i.e. A1, A2, B1, B2, $C 1, C 2, D 1$ and D2. Each subgroup comprised of 6 animals. Animals of each subgroup were kept in a separate cage. The subgroup A1 was the control group for B1, C1 and D1 experimental subgroups, while the subgroup A2 was the control group for experimental subgroups of B2, $\mathrm{C} 2$ and D2. Animals in the control subgroups $\mathrm{A} 1$ and $\mathrm{A} 2$ received the vehicle (3\% DMSO, $1 \%$ Tween 80 and $96 \%$ normal saline) for 7 and 14 days, respectively. The animals in subgroups B1, $\mathrm{C} 1$ and D1 received SCS once daily through the intraperitoneal route at doses of $5 \mathrm{mg} / \mathrm{kg}, 25 \mathrm{mg} /$ $\mathrm{kg}$ and $50 \mathrm{mg} / \mathrm{kg}$, respectively for consecutive 7 days. Likewise, SCS was intraperitoneally administered to animals in subgroups B2 at 5 $\mathrm{mg} / \mathrm{kg}, \mathrm{C} 2$ at $25 \mathrm{mg} / \mathrm{kg}$ and D2 at $50 \mathrm{mg} / \mathrm{kg}$ for consecutive 14 days. The experimental plan is shown in Table-I.

\begin{tabular}{|c|c|c|}
\hline Groups & Subgroups & Dose of Drug \\
\hline \multirow{2}{*}{$\begin{array}{l}\text { Control } \\
\text { Group A }\end{array}$} & $A 1(n=6)$ & $\begin{array}{c}10 \mathrm{ml} / \mathrm{kg}(3 \% \text { DMSO, } 1 \% \\
\text { Tween80 and } 96 \% \text { normal } \\
\text { saline) for } 7 \text { days }\end{array}$ \\
\hline & $A 2(n=6)$ & $\begin{array}{c}10 \mathrm{ml} / \mathrm{kg} \text { (3\% DMSO, } 1 \% \\
\text { Tween80 and } 96 \% \text { normal } \\
\text { saline) for } 14 \text { days }\end{array}$ \\
\hline \multirow{2}{*}{$\begin{array}{l}\text { Experimental } \\
\text { Group B }\end{array}$} & $B 1(n=6)$ & $5 \mathrm{mg} / \mathrm{kg}$ for 7 days \\
\hline & $B 2(n=6)$ & $5 \mathrm{mg} / \mathrm{kg}$ for 14 days \\
\hline \multirow{2}{*}{$\begin{array}{l}\text { Experimental } \\
\text { Group C }\end{array}$} & $C 1(n=6)$ & $25 \mathrm{mg} / \mathrm{kg}$ for 7 days \\
\hline & $\mathrm{C} 2(\mathrm{n}=6)$ & $25 \mathrm{mg} / \mathrm{kg}$ for 14 days \\
\hline \multirow{2}{*}{$\begin{array}{l}\text { Experimental } \\
\text { Group D }\end{array}$} & $\mathrm{D} 1(\mathrm{n}=6)$ & $50 \mathrm{mg} / \mathrm{kg}$ for 7 days \\
\hline & $\mathrm{D} 2(\mathrm{n}=6)$ & $50 \mathrm{mg} / \mathrm{kg}$ for 14 days \\
\hline
\end{tabular}

At the end of 7 and 14 days, the animals were sacrificed and their testes were surgically 
removed. The testes were weighted along with epididymis. They were then placed in labeled jars containing $10 \%$ neutral buffered formaldehyde. After 48 hours, the tissues were dehydrated in graded ethanol solutions (70-100\%), each for $1 \mathrm{~h}$. The tissues were then cleared in alcoholxylene solution and then in $100 \%$ xylene with two changes each for $1 \mathrm{~h}$ at $45-47^{\circ} \mathrm{C}$ under constant stirring. The tissues were then infiltrated with paraffin wax and were then embedded. The embedded tissues were sectioned through a rotary microtome at 4-5 micron and were then stained with hematoxylin and eosin and periodic acid-Schiff for microscopic evaluation. ${ }^{9-11}$

The tissue slides were examined under a light microscope for various parameters including degeneration of germ cells, multinucleate aggregation, depletion of germ cells, exfoliation of germ cells, vacuolization of the germinal epithelium of the seminiferous tubules, contraction of tubules, dilatation of tubules, retention of spermatids, necrosis of the seminiferous tubules, atrophy, hypertrophy, hyperplasia and adenoma of Leydig's cell and disorganization of the tubular contents. The histopathological changes occurring in the testis were examined under a $400 x$ original magnification using a trinocular microscope. The level of spermatogenesis was evaluated using the modified Johnsen scoring system. ${ }^{12}$

The morphometric analysis was performed for the measurement of seminiferous tubular diameter, germinal epithelium thickness, and area of interstitial cells of Leydig under high power field. These measurements were conducted using the Nikon microscope (ECLIPSE Ci-L) with a standalone camera control unit (DS-L3).

The histopathological changes were evaluated by an experienced pathologist who was blinded to the various treatment groups. The quantitative data were expressed as mean \pm standard deviation (SD) or standard error of the mean (SEM). Statistical analyses were carried out using one-way ANOVA or two-way repeated measures ANOVA followed by appropriate post hoc tests. A $P$ value less than 0.05 was accepted as statistically significant.

\section{RESULTS}

After 7 days, the group of mice treated with the vehicle (A1) showed a normal gross behavioral profile. The mice in the subgroups administered with the tested doses of SCS at 5, 25 and $50 \mathrm{mg} /$ $\mathrm{kg}$ (groups B1, C1 and D1) were also observed to perform their normal general activity. Moreover, no aggressive behaviors were observed during the 7 days of observation.

After 14 days, the group of mice treated with the vehicle (A2) exhibited a normal behavioral and locomotor profile. The animals that were administered with the 5,25 and $50 \mathrm{mg} / \mathrm{kg}$ doses of SCS (groups B2, C2 and D2) were also grossly observed after dosing in their respective cages. It was found that these doses have no gross effect on the behavior as well as on the locomotion.

\section{Effect of salicylidene salicylhydrazide on body weight}

After 7 days of consecutive treatment with SCS, the animals in the various groups did not show any statistically significant change in the body weight as no significant difference was observed in the groups of mice administered with SCS at the tested doses of 5,25 and $50 \mathrm{mg} / \mathrm{kg}$ (groups B1, C1 and D1) as compared to the vehicle treated group (group A1). Similarly, administration of SCS for 14 days has no significant effect on the body weight of animals allocated to the various treated groups (groups B2, C2 and D2) (Figures$1 \mathrm{~A}$ and 1B).

The different groups of animals administered with the tested doses of SCS at 5, 25 and 25 $\mathrm{mg} / \mathrm{kg}$ (groups B1, C1 and D1) have shown no significant alterations, when their diameters were measured as compared to the vehicle treated control animals' group (group A1) after 7 days. After 14 days, the groups of animals administered with SCS at 5,25 and $50 \mathrm{mg} / \mathrm{kg}$ (groups B2, $\mathrm{C} 2$ and D2) showed a non-significant decrease in their seminiferous tubules diameter when compared to that of the vehicle treated animals' group (Figures-6A and 6B). 

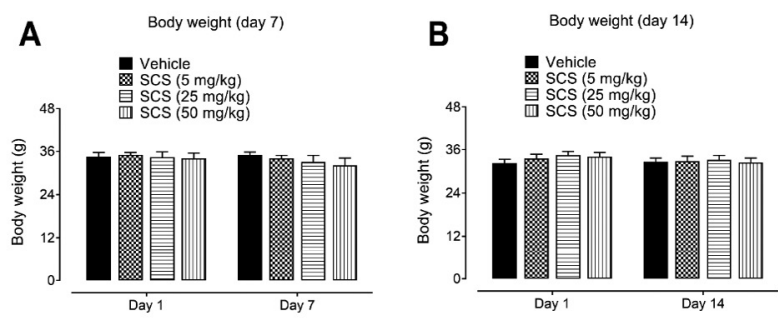

C Relative testis weight (day 7)

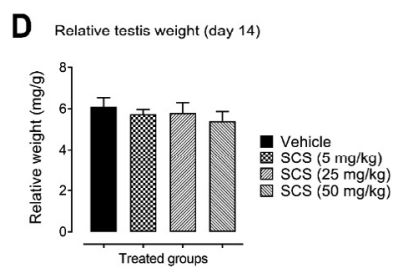

Figure-1. Effect of salicylidene salicylhydrazide (SCS) at 5,25 , and $50 \mathrm{mg} / \mathrm{kg}$ on body weight (A and $B$ ) and relative testes weight $(C$ and $D)$ after 7 and 14 days of administration. Each column represents mean body weight or relative testes weight in grams $(\mathrm{g})$ or milligrams $(\mathrm{mg}) \pm$ SEM. SCS groups were compared with the vehicle groups. No significant difference was observed, two-way repeated measures ANOVA followed by Dunnett's post hoc test, $n=6$ mice per group.

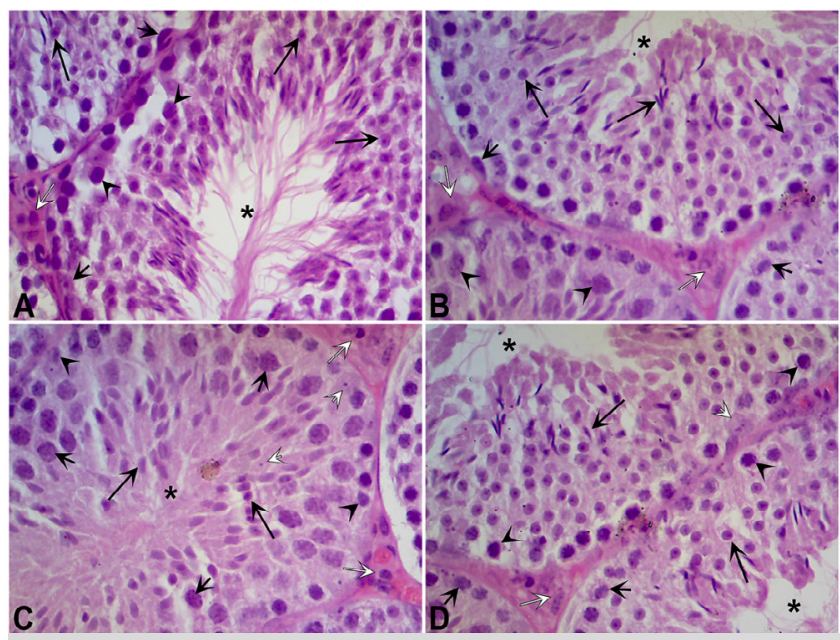

Figure-2. Representative photomicrographs (H\&E, $400 x$ ) of the germinal epithelium of seminiferous tubules from testes of mice after 7 days of treatment with vehicle (A) showing normal histology of dark and pale spermatogonia (arrow heads), numerous pachytene spermatocytes (small arrows), rounded and elongated spermatids (large arrows) with their tails protruding into the lumen (asterisk), and Leydig cells (white arrow) in the interstitial compartment. Normal histological features of the germinal epithelium were observed in the testes of mice treated with SCS at $5 \mathrm{mg} / \mathrm{kg}(\mathrm{B}), 25 \mathrm{mg} / \mathrm{kg}$ (C), and at $50 \mathrm{mg} / \mathrm{kg}(\mathrm{D})$.

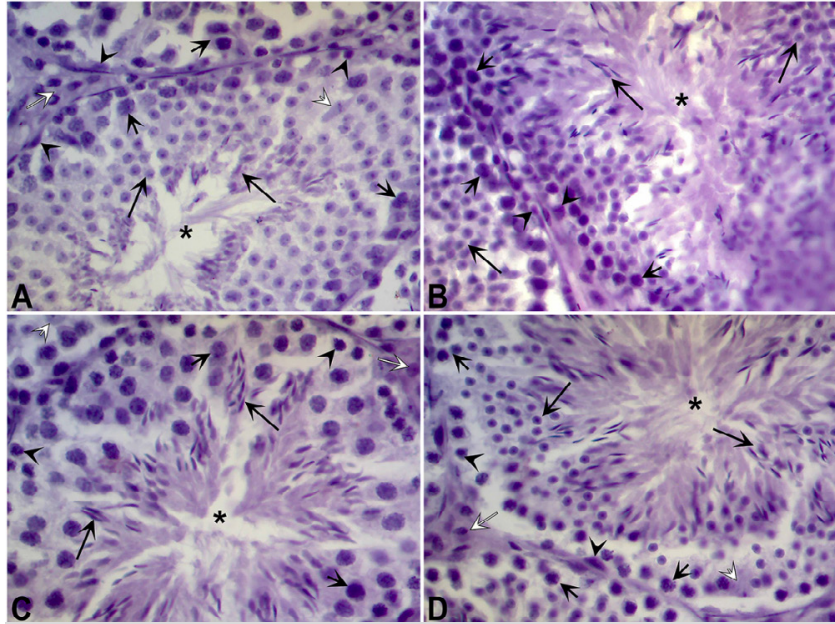

Figure-3. Representative photomicrographs (PAS, 400x) of a section of germinal epithelium from the testes of mice after 7 days of administration with the vehicle (A) showing the normal histology of interstitial cells of Leydig (large white arrow), pale and dark spermatogonia (arrow heads), primary spermatocytes (small arrows), numerous rounded spermatids (large arrow) with tails of elongated spermatids (large arrow) appeared protruding into the lumen and Sertoli cell (small white arrow). Normal histology of germinal epithelium lining the seminiferous tubules was observed in the group of mice treated with SCS at $5 \mathrm{mg} / \mathrm{kg}(B), 25 \mathrm{mg} / \mathrm{kg}$ (C), and $50 \mathrm{mg} / \mathrm{kg}(\mathrm{D})$.

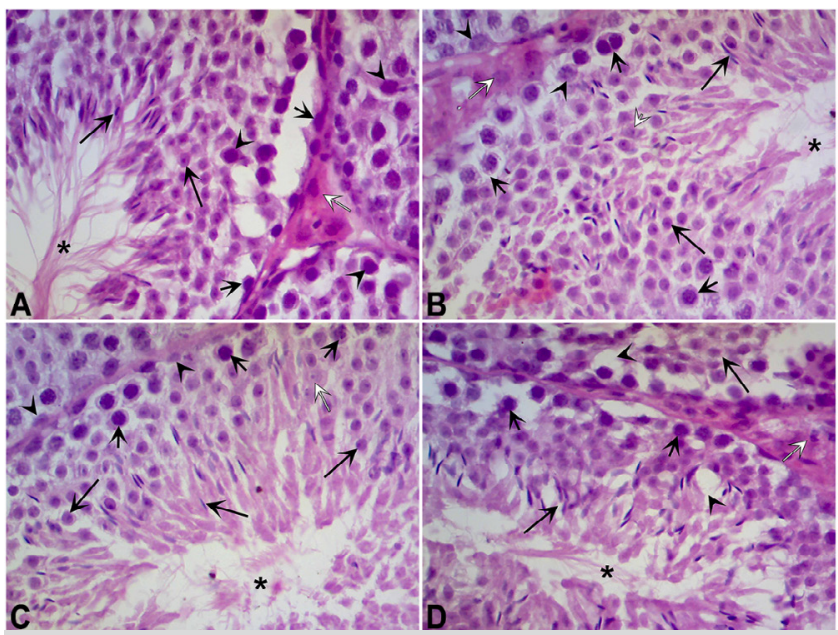

Figure-4. Representative photomicrographs (H\&E, 400x) of the germinal epithelium of seminiferous tubules from testes of mice after 14 days of treatment with vehicle (A) showing normal histological appearance of spermatogonia (small arrows), pachytene spermatocytes (arrow heads), rounded spermatids (large arrow) as well as elongated spermatids (large arrow) with their tails extending into the luminal space (asterisk) and numerous interstitial cells of Leydig (white arrow). Normal histology of the germinal epithelium cells lining the seminiferous tubules was observed in the testes of mice treated with SCS at $5 \mathrm{mg} / \mathrm{kg}$ (B), $25 \mathrm{mg} / \mathrm{kg}$ (C), and $50 \mathrm{mg} / \mathrm{kg}$ (D). The major histopathological finding in the 50 $\mathrm{mg} / \mathrm{kg}$ treated group (D) was the epithelial vacuolization as revealed from the numerous vacuoles (arrow heads) that are visible in the germinal epithelium. 


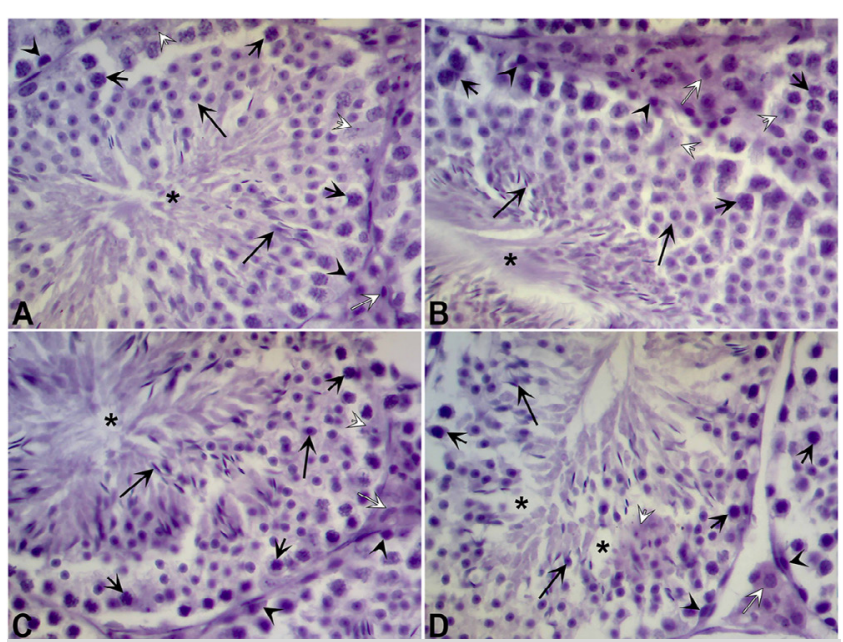

Figure-5. Representative photomicrograph (PAS, $400 x$ ) of a section of germinal epithelium from the testes of mice after 14 days of administration with the vehicle (A) showing normal histological appearance of spermatogonia (arrow heads), primary spermatocytes (small arrows), Sertoli cells (small white arrow), numerous rounded spermatids (large arrow) with their tails extending into the lumen (asterisk), and interstitial cells of Ledig (large white arrow). Normal appearing germ cells are visible in the groups of animals treated with SCS at $5 \mathrm{mg} / \mathrm{kg}$ (B), $25 \mathrm{mg} / \mathrm{kg}$ (C), and $50 \mathrm{mg} / \mathrm{kg}$ (D). In the $50 \mathrm{mg} /$ kg SCS group (D), there is loosening of the germinal epithelium containing vacuoles (asterisks) and dilatation of interstitial space.
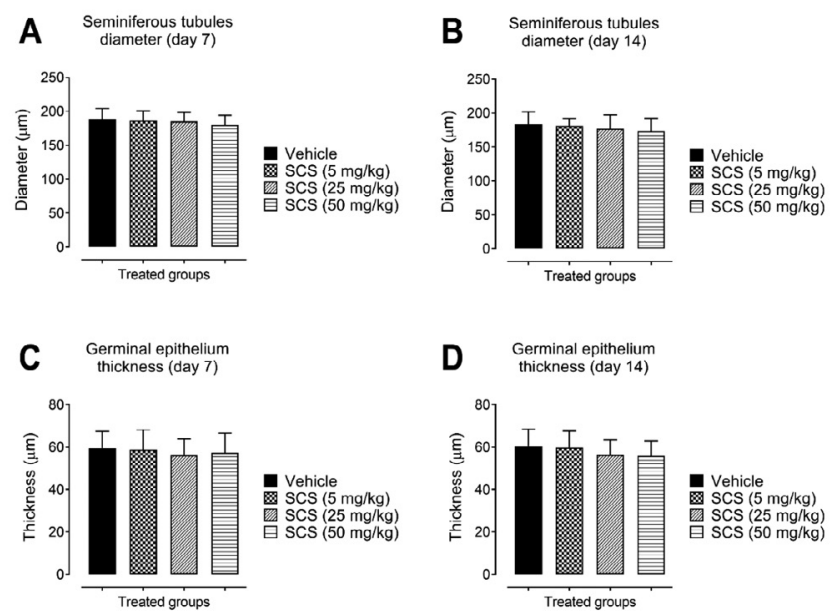

Figure-6. Effect of salicylidene salicylhydrazide (SCS) at 5,25 , and $50 \mathrm{mg} / \mathrm{kg}$ on seminiferous tubules diameter (A and B) and germinal epithelium thickness (C and D) after 7 and 14 days of administration. Each column represents mean seminiferous tubules diameter or germinal epithelium thickness in $\mu \mathrm{m} \pm$ SD. SCS groups were compared with the vehicle groups. No significant difference was observed, oneway ANOVA followed by Dunnett's post hoc test, $\mathbf{n}=$ 25 tubules per group.
The groups of animals administered with the tested doses of SCS at 5,25 and $50 \mathrm{mg} / \mathrm{kg}$ (groups B1, C1 and D1) showed no significant changes in the height of the germinal epithelium lining the seminiferous tubules. The groups of animals administered with SCS at 5, 25 and 50 $\mathrm{mg} / \mathrm{kg}$ (groups B2, C2 and D2) showed a nonsignificant dose-dependent reduction in the height of germinal epithelium, with a prominent decrease was noted with the higher dose treated group (Figure-6C and 6D).

After 7 days, the groups of animals administered with SCS at 5,25 and $50 \mathrm{mg} / \mathrm{kg}$ (groups B1, C1 and D1) showed no apparent change in the area among the seminiferous tubules in addition to a slight increase for the $50 \mathrm{mg} / \mathrm{kg}$ treated animals group, as compared to the vehicle treated animals control group (group A1). After 14 days, the groups of animals treated with SCS at 5,25 and 50 $\mathrm{mg} / \mathrm{kg}$ (groups B2, C2 and D2) produced a nonsignificant dose-dependent increase in the area of the interstitial space among the seminiferous tubules when compared to the vehicle treated group (group A2) (Figures-7A and 7B).

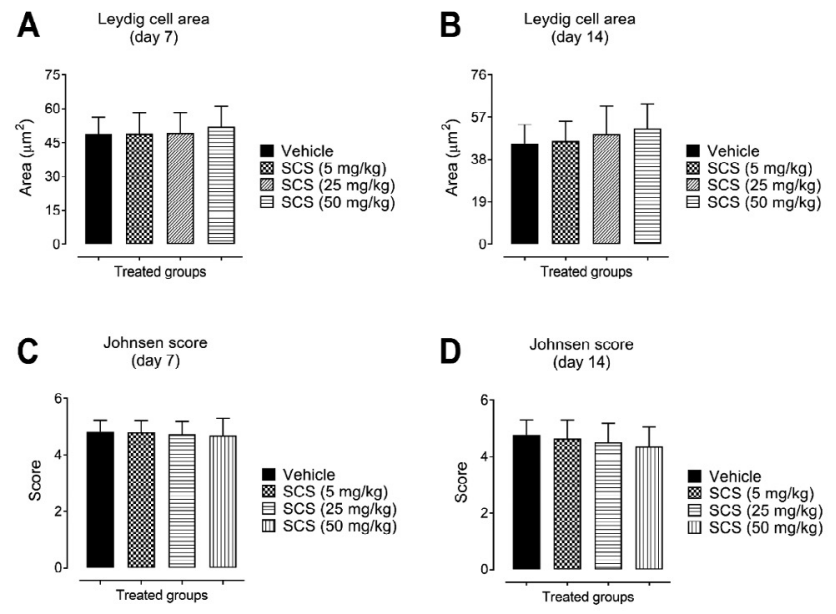

Figure-7. Effect of salicylidene salicylhydrazide (SCS) at 5,25 , and $50 \mathrm{mg} / \mathrm{kg}$ on Leydig cell area (A and $B$ ) and spermatogenesis using modified Johnsen score (C and D) after 7 and 14 days of administration. Each column represents mean Leydig cell area in $\mu \mathrm{m}^{2}$ or Johnsen scores \pm SD. SCS groups were compared with the vehicle groups. No significant difference was observed, one-way ANOVA followed by Dunnett's post hoc test, $n=25$ areas per group. 
The groups of mice treated with SCS at 5, 25 and $50 \mathrm{mg} / \mathrm{kg}$ (groups B1, C1 and D1) showed no remarkable changes in the Johnsen scores as compared to the scores obtained for the vehicle administered group (group A1) after 7 days. After 14 days of treatment, the groups of animals treated with SCS at 5,25 and $50 \mathrm{mg} / \mathrm{kg}$ (groups B2, C2 and D2) showed a non-significant dose-dependent reduction in the scores of the spermatogenesis with a prominent decrease in the level of spermatogenesis was noted for the $50 \mathrm{mg} / \mathrm{kg}$ dose group (Figures-7C and 7D).

The testicular toxicity evaluation of mice treated with the different doses of SCS was compared with respect to the experimental time-periods of day 7 and day 14. No significant toxicological changes in the seminiferous tubules were observed on day 7 among the different treated groups. After 14 days, a variation in the testicular toxicity was noted. There was a slight increase in the toxicity for the $5 \mathrm{mg} / \mathrm{kg}$ group, while a prominent increase in toxicity was observed for the groups of SCS treated mice at 25 and $50 \mathrm{mg} /$ $\mathrm{kg}$ doses (Figure-8A).

The testicular toxicity observed in the treated mice after day 7 and day 14 was compared with respective to the different doses of SCS i.e. 5, 25 and $25 \mathrm{mg} / \mathrm{kg}$. The SCS treated group at $5 \mathrm{mg} / \mathrm{kg}$ has no differences in testicular changes between the tested days. For the $25 \mathrm{mg} / \mathrm{kg}$ dose, a slight increase in the toxicity was observed on day 14 as compared to day 7 . The higher tested dose of $50 \mathrm{mg} / \mathrm{kg}$ showed a marked toxicological change on day 14 in comparison to changes observed on day 7 of the experiment (Figure-8B).

\section{DISCUSSION}

In the present study, salicylidene salicylhydrazide was assessed for its toxicological propensity in mice. The testicular tissue was evaluated for any morphological alterations occurring after repeated administration for 7 and 14 days. It was observed that the 14 days treatment with the 50 $\mathrm{mg} / \mathrm{kg}$ dose produced histopathological changes in the seminiferous tubules.
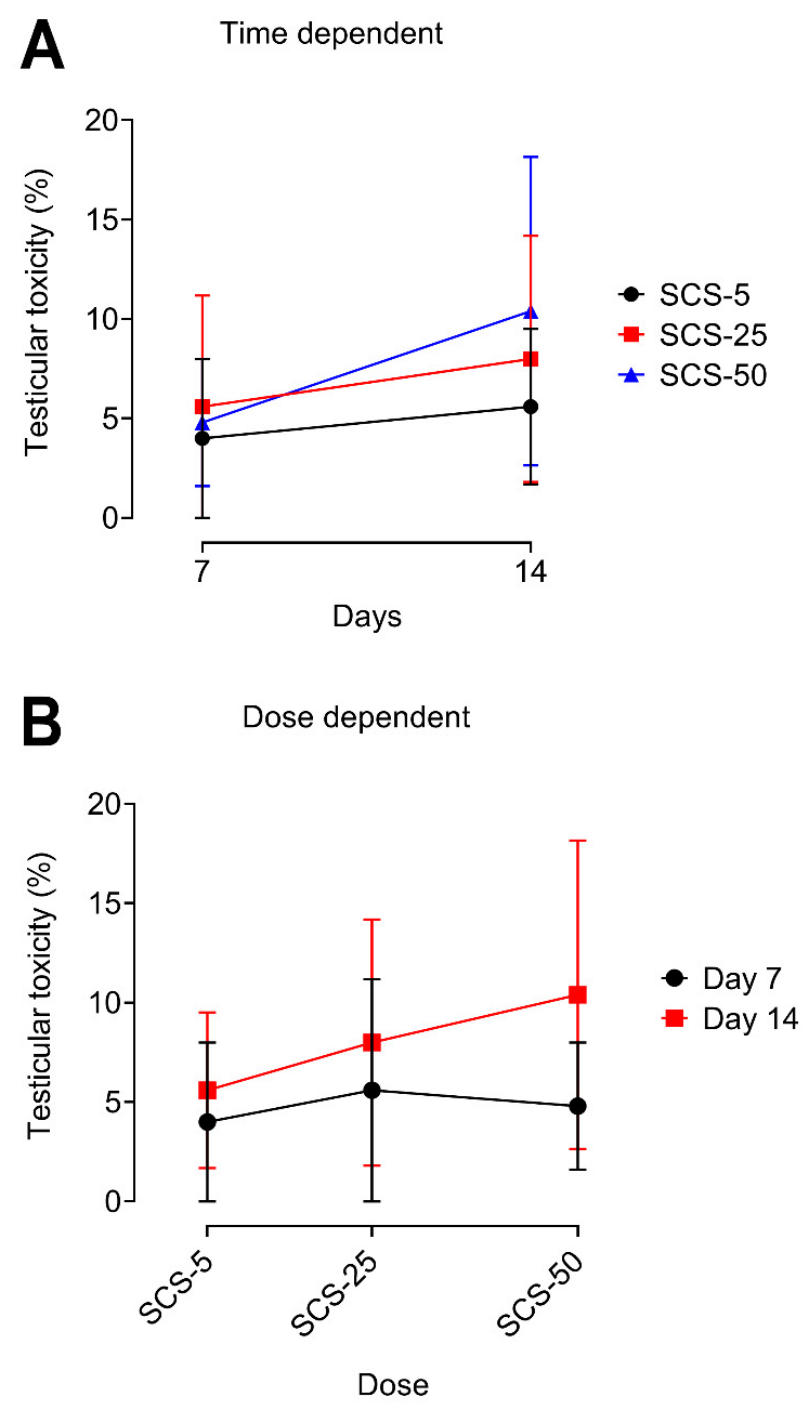

Figure-8. Time dependent (A) and dose dependent (B) testicular toxicity evaluation of salicylidene salicylhydrazide (SCS) at 5,25 , and $50 \mathrm{mg} / \mathrm{kg}$ in mice. Each symbol represents mean percentage testicular toxicity \pm SEM. SCS groups were compared on days 7 and 14 (time dependent) or at different doses on respective days (dose dependent). No significant difference was observed, two-way repeated measures ANOVA followed by Sidak's multiple comparison post hoc test.

Exposure to the antimicrobial agent, mequindox at 55 and $110 \mathrm{mg} / \mathrm{kg}$ doses produce necrosis of the seminiferous tubules that is associated with germinal epithelium exfoliation, arresting of spermatogenesis, atrophy and disappearance of spermatogenic cells. ${ }^{13}$ The ingestion of doxorubicin at $7.5 \mathrm{mg} / \mathrm{kg}$ is associated with atrophy 
of the seminiferous tubules along with a loss of spermatogenic cells. It also causes vacuolization of the germinal epithelium containing multinuclear giant cells and other degenerative changes. In addition, there is also edematous changes in the interstitial tissue with a loss of interstitial cells of Leydig. ${ }^{14}$ The degenerative changes induced by the administration of adriamycin at a dose of $10 \mathrm{mg} / \mathrm{kg}$ include reduction in the size of the germinal epithelium, formation of giant cells and thickening of the basal layer of the seminiferous tubules. ${ }^{15}$ The administration of methotrexate group at $20 \mathrm{mg} / \mathrm{kg}$ is associated with a loss of spermatogenic cells and Sertoli supporting cells from the germinal epithelium along with vacuole formation, inflammatory changes in the interstitial space and degeneration of interstitial cells of Leydig. ${ }^{16}$ Similarly, cisplatin administration at $3 \mathrm{mg} /$ $\mathrm{kg}$ is also associated with loss of spermatogenic cells and Sertoli cells. ${ }^{17}$

In this study, the potential toxic nature of salicylidene salicylhydrazide was observed by measuring the diameter of the seminiferous tubules, thickness of the germinal epithelium and area of the Leydig interstitial cells in the different tested group. Although the low-dose and short duration (for both low and high doses) were observed to be safe with regard to the testicular histopathological changes; however, the 14 days treatment with the $50 \mathrm{mg} / \mathrm{kg}$ dose was found to have an effect on these morphometric parameters in the testicular tissue. The administration of quinine is shown to produce a gradual decline in the diameter of the seminiferous tubules after chronic dosing along with an increase in the volume of connective tissue stroma in the interstitium. ${ }^{18}$ Chronic exposure to malathion is associated with a decrease in the germinal epithelium thickness, luminal, and tubular diameter of the seminiferous tubules. ${ }^{19}$ Cisplatin has been shown to produce significant a decrease in the seminiferous tubules diameter and an increase in the lumen diameter of tubules. ${ }^{20} \mathrm{~A}$ significant decrease in the volume of the seminiferous tubules and an increase in the volume of the interstitium have been observed after administration of cocaine and caffeine. ${ }^{21}$ Administration of ribavirin also produce a decrease in the seminiferous tubular diameter and epithelial height of the seminiferous tubules. ${ }^{22}$ Moreover, dexamethasone administration has also shown to be associated with a decrease in the seminiferous tubules diameter and a reduction in the height of seminiferous germinal epithelium. ${ }^{23}$ Administration of cannabis extract at doses of 40 , 60 and $80 \mathrm{mg} / \mathrm{kg}$ have detrimental effect on the testis as revealed from the significant decrease in the seminiferous tubules diameter along with shrinkage of tubules. ${ }^{24}$ The selenium treated animals at a dose of $8 \mathrm{ppm}$ has a considerable effect on the testicular tissue as revealed from the decrease in the diameter of the seminiferous tubules, reduction in the height of the germinal epithelium and number of spermatogenic cells. ${ }^{25}$ Likewise, ingestion of fluoride was also associated with a decrease in the epithelial height and tubular diameter of testis. ${ }^{26}$

In this study, any testicular toxicity associated with the administration of salicylidene salicylhydrazide was investigated using modified Johnsen scoring system, which evaluates the level of spermatogenesis. The $50 \mathrm{mg} / \mathrm{kg}$ treated group was observed to produce aberrations in the spermatogenesis process after 14 days of treatment. Exposure to chemicals and drugs have been shown to produce changes in the Johnsen scoring system that are suggestive of alterations in the spermatogenesis process. The anticancer drug, cisplatin also has a toxicological propensity for the seminiferous tubules and associated with a significant decrease in the Johnsen's scores. ${ }^{27}$ The Johnsen's tubular biopsy score for the groups of animals treated with doxorubicin was significantly lowered than the control groups animals and an increase in the tubular scoring was observed after the doxorubicin animals were given a combination of zinc and alogliptin. ${ }^{28}$ Application of the Johnsen's testicular biopsy scoring system to the seminiferous tubules of testes from the sildenafil, tadalafil and tramadol administered animals revealed a significant decrease in comparison to the control group after chronic administration with high doses of phosphodiesterase-5 inhibitors and tramadol. ${ }^{29}$ Similarly, the Johnsen's testicular biopsy scores were also employed to validate the underlying histopathological changes occurring in the 
testicular tissues in the studies conducted on cadmium, ${ }^{2}$ methyl parathion ${ }^{30}$ and a significant decrease was noted in the scores after administration of these agents.

These prospective controlled studies should look in-depth for the effect of salicylidene salicylhydrazide on complete semen analysis, serum concentrations of reproductive hormones including testosterone, analysis of testicular glucose, lactate and lactate dehydrogenase, assay of testicular enzymatic and non-enzymatic antioxidants and checking for markers of apoptosis in the testes. In addition, specific staining procedures for cellular apoptosis along with electron and confocal microscopic ultrastructural techniques can also be utilized.

\section{CONCLUSION}

From these findings, it can be concluded that salicylidene salicylhydrazide is considered to be relatively safe. However, its absolute safety can only be established if further thorough studies are designed.

Copyright $($ )

\section{REFERENCES}

1. Hukkanen RR, Halpern WG, Vidal JD: Regulatory forum opinion piece: Review of FDA draft guidance testicular toxicity-evaluation during drug development guidance for industry. Toxicologic Pathology 2016, 44:927-930.

2. Nna VU, Ujah GA, Mohamed M, Etim KB, Igba BO, Augustine ER, Osim EE: Cadmium chloride-induced testicular toxicity in male wistar rats; prophylactic effect of quercetin, and assessment of testicular recovery following cadmium chloride withdrawal. Biomedicine \& Pharmacotherapy 2017, 94:109-123.

3. Cyr DG: Male reproductive toxicology and the role of immunohistochemistry. In Technical Aspects of Toxicological Immunohistochemistry. Springer; 2016: 95-111

4. Coder PS, Sloter ED, Stump DG, Nemec MD, Bowman CJ: 11.03 - Evaluation of a male reproductive toxicant. in comprehensive toxicology (Second Edition). Edited by McQueen CA. Oxford: Elsevier; 2010: 61-86
5. Ainscough EW, Brodie AM, Denny WA, Finlay GJ, Gothe SA, Ranford JD: Cytotoxicity of salicylaldehyde benzoylhydrazone analogs and their transition metal complexes: Quantitative structure-activity relationships. Journal of inorganic biochemistry 1999, $77: 125-133$.

6. Johnson DK, Murphy TB, Rose NJ, Goodwin WH, Pickart L: Cytotoxic chelators and chelates 1. Inhibition of DNA synthesis in cultured rodent and human cells by aroylhydrazones and by a copper (II) complex of salicylaldehyde benzoyl hydrazone. Inorganica Chimica Acta 1982, 67:159-165.

7. Thompson S, Wheat L, Brown N, Wingrove P, Pillai G, Whiting P, Adkins C, Woodward C, Smith A, Simpson $P$ : Salicylidene salicylhydrazide, a selective inhibitor of $\beta 1$-containing GABAA receptors. British journal of pharmacology 2004, 142:97-106.

8. Rukh L, Ali G, Ullah R, Islam NU, Shahid M: Efficacy assessment of salicylidene salicylhydrazide in chemotherapy associated peripheral neuropathy. European Journal of Pharmacology 2020, 888:173481.

9. Creasy DM: Histopathology of the male reproductive system I: Techniques. Current Protocols in Toxicology 2002, 12:16.13.11-16.13.18.

10. Shahid M, Subhan F: Comparative histopathology of acetaminophen induced hepatotoxicity in animal models of mice and rats. Pharmacologyonline 2014, 3:32-43.

11. Shahid M, Subhan F: Protective effect of Bacopa monniera methanol extract against carbon tetrachloride induced hepatotoxicity and nephrotoxicity. Pharmacologyonline 2014, 2:18-28.

12. Mustafa S, Wei Q, Ennab W, Lv Z, Nazar K, Siyal FA, Rodeni S, Kavita NM, Shi F: Resveratrol ameliorates testicular histopathology of mice exposed to restraint stress. Animals (Basel) 2019, 9:743.

13. Liu Q, Lei Z, Huang A, Lu Q, Wang X, Ahmed S, Awais I, Yuan Z: Mechanisms of the testis toxicity induced by chronic exposure to mequindox. Frontiers in pharmacology 2017, 8:679.

14. Gurel C, Kuscu GC, Buhur A, Dagdeviren M, Oltulu F, Karabay Yavasoglu NU, Yavasoglu A: Fluvastatin attenuates doxorubicin-induced testicular toxicity in rats by reducing oxidative stress and regulating the blood-testis barrier via mTOR signaling pathway. Human and Experimental Toxicology 2019, 38:13291343. 
15. Ateşşahin A, Karahan Iz, Yılmaz S, Çeribaşı AO, Bulmuş Ö: Lycopene prevents adriamycin-induced testicular toxicity in rats. Fertility and Sterility 2006, 85:12161222.

16. Kamel ME, Mohammad HM, Maurice C, Hagras MM: Ginseng nanoparticles protect against methotrexateinduced testicular toxicity in rats. Egyptian Journal of Basic and Clinical Pharmacology 2019, 9:Article ID 101397.

17. Prihatno SA, Padeta I, Larasati AD, Sundari B, Hidayati A, Fibrianto $\mathrm{YH}$, Budipitojo $\mathrm{T}$ : Effects of secretome on cisplatin-induced testicular dysfunction in rats. Veterinary world 2018, 11:1349-1356.

18. Osinubi A, Noronha C, Okanlawon A: Morphometric and stereological assessment of the effects of longterm administration of quinine on the morphology of rat testis. West African Journal of Medicine 2005, 24:200-205.

19. Bustos-Obregón E, Del Río FC, Sarabia L: Morphometric Analysis of Mice Testicular Tubules after Administration of Malathion and Maca. International Journal of Morphology 2007, 25:245-248.

20. Akunna G, Obikili E, Anyawu G, Esom E: Histochemical and morphometric evidences of the curative role of aqueous zest extract of Citrus sinensis on antineoplastic drug-induced testicular degeneration in animal models. European Journal of anatomy 2018, 22:497-507.

21. González CR, González B, Matzkin ME, Muñiz JA, Cadet JL, Garcia-Rill E, Urbano FJ, Vitullo AD, Bisagno V: Psychostimulant-induced testicular toxicity in mice: Evidence of cocaine and caffeine effects on the local dopaminergic system. PLoS One 2015, 10.

22. Batool A, Farzana F: Ribavirin exposure induces morphometric changes in the seminiferous tubules of testes in albino rats. Biomedica 2013, 29:256-262.
23. Khorsandi L, Mirhoseini M, Mohamadpour M, Orazizadeh $M$, Khaghani S: Effect of curcumin on dexamethasone-induced testicular toxicity in mice. Pharmaceutical biology 2013, 51:206-212.

24. Mandal TK, Das NS: Testicular toxicity in cannabis extract treated mice: Association with oxidative stress and role of antioxidant enzyme systems. Toxicology and Industrial Health 2010, 26:11-23.

25. Kaur R, Kaur K: Effects of dietary selenium (SE) on morphology of testis and cauda epididymis in rats. Indian journal of Physiology and Pharmacology 2000, 44:265-272.

26. Kumar A, Susheela A: Effects of chronic fluoride toxicity on the morphology of ductus epididymis and the maturation of spermatozoa of rabbit. International Journal of Experimental Pathology 1995, 76:1-11.

27. Soni KK, Zhang LT, You JH, Lee SW, Kim CY, Cui WS, Chae HJ, Kim HK, Park JK: The effects of MOTILIPERM on cisplatin induced testicular toxicity in SpragueDawley rats. Cancer Cell International 2015, 15:121.

28. Kabel AM: Zinc/alogliptin combination attenuates testicular toxicity induced by doxorubicin in rats: Role of oxidative stress, apoptosis and TGF- $\beta 1 /$ NFKB signaling. Biomedicine \& Pharmacotherapy 2018, 97:439-449.

29. Nna VU, Udefa AL, Ofutet EO, Osim EE: Testicular and epididymal histology of rats chronically administered high doses of phosphodiesterase-5 inhibitors and tramadol. Nigerian Journal of Physiological Sciences 2017, 32:55-61.

30. El-Gerbed MS: Histopathological and ultrastructural effects of methyl parathion on rat testis and protection by selenium. Journal of Applied Pharmaceutical Science 2013, 3: S53-S63.

\begin{tabular}{|c|c|c|c|}
\hline \multicolumn{4}{|c|}{ AUTHORSHIP AND CONTRIBUTION DECLARATION } \\
\hline No. & Author(s) Full Name & Contribution to the paper & Author(s) Signature \\
\hline 1 & Shagufta Sultana & $\begin{array}{l}\text { Overall conduction of research } \\
\text { and analysis of results. }\end{array}$ & \\
\hline 3 & Falak Naz & Introduction writing. & \\
\hline 4 & Zainab Rehman & Discussion writing. & \\
\hline 5 & Shazia Iftikhar & Discussion writing. & \\
\hline
\end{tabular}

